\title{
A LAG-TIME MODEL FOR SUBSTRATE AND PRODUCT DIFFUSION THROUGH HYDROXYETHYLCELLULOSE GELS USED FOR IMMOBILIZATION OF YEAST CELLS*
}

\author{
Elena Velickova ${ }^{a}$, Maja Cvetkovska ${ }^{b}$, Slobodanka Kuzmanovaa, \\ Eleonora Winkelhausen ${ }^{\text {a* }}$
}

\author{
${ }^{a}$ Department of Food Technology and Biotechnology, \\ ${ }^{\mathrm{b}}$ Department of Polymer Science, \\ Faculty of Technology and Metallurgy, University Ss. Cyril and Methodius, \\ Rudjer Bošković 16, 1000 Skopje, Republic of Macedonia \\ eleonora@tmf.ukim.edu.mk
}

\begin{abstract}
Diffusion models were tested to select the most appropriate model for measuring the diffusion of glucose and ethanol trough hydroxyethylcellulose (HEC) cryogels. The lag-time model was selected as accurate, rapid and reliable for evaluating the diffusivity of the solutes. The diffusion coefficient of glucose through the HEC cryogel loaded with cells was estimated to be $6.9 \times 10^{-6} \mathrm{~cm}^{2} / \mathrm{s}$, while the diffusion coefficient of ethanol had a value of $2.5 \times 10^{-5} \mathrm{~cm}^{2} / \mathrm{s}$. The cells inside the gel matrix were not a barrier for the transport of the solute molecules. The diffusion properties of the cryogel were also examined in a real system. The parameters characterizing the repeated batch fermentation of glucose to ethanol by entrapped Saccharomyces cerevisiae cells gave evidence of very good diffusion properties of the HEC gel.
\end{abstract}

Key words: immobilization; Saccharomyces cerevisiae; diffusion; hydroxyethylcellulose; cryogel

\section{ОПРЕДЕЛУВАЊЕ НА ДИФУЗИЈА НА СУПСТРАТ И ПРОДУКТ НИЗ ХИДРОКСИЕТИЛЦЕЛУЛОЗНИ ГЕЛОВИ НАМЕНЕТИ ЗА ИМОБИЛИЗАЦИЈА НА КВАСОЧНИ КЛЕТКИ СО „LAG-TIMЕ“ МОДЕЛ}

За да се селектира најпогоден модел за мерење на дифузијата на глукоза и етанол низ хидроксиетилцелулозен (НЕС) гел беа тестирани повеќе дифузиони модели. Како прецизен, брз и сигурен метод за определување на дифузивноста на растворените компоненти беше избран моделот „lag-time“. Користејќи го овој модел, беа определени коефициенти на дифузија на глукозата и на етанолот низ (НЕС) гелот исполнет со клетки. Коефициентите на дифузија на глукоза и етанол изнесуваат $6,9 \times 10^{-6} \mathrm{~cm}^{2} / \mathrm{s}$ и $2,5 \times 10^{-5} \mathrm{~cm}^{2} / \mathrm{s}$, соодветно. Клетките во гелот не претставуваа пречка за преносот на растворените компоненти низ него. Дифузионите својства на криогелот беа испитани и во реален систем. Параметрите што ја опишуваат повеќекратната ферментација на глукозата до етанол со имобилизирани клетки на Saccharomyces cerevisiae ги потврдија наодите за добрите дифузиони својства на (НЕС) гелот.

Клучни зборови: имобилизација; Saccharomyces cerevisiae; дифузија; хидроксиетилцелулоза; криогел. 


\section{INTRODUCTION}

Immobilization of biocatalysts in gels, over the years has gained attention of many biotechnologists, because such systems display better operational stability and higher efficiency. The selection of a proper carrier is of great importance for successful performance of the immobilized cell system. The cell carrier should have good permeability, chemical, mechanical and thermal stability, suitable shape and insolubility [1-3]. In recent years, there has been a growing interest for the immobilization of microbial cells in hydrogels. Several methods have been proposed for modification of the structure of the polymer network and the size of pores, among which is the preparation of new generation of hydrogels and cryogels [4-6]. The immobilized systems have a number of advantages, and few disadvantages. One of the disadvantages is that the reaction rate of an immobilized system is frequently restricted by the diffusion of substrate within particles. Therefore, information on diffusion coefficients in gels is of great importance.

Bioprocesses carried out with immobilized viable cells are complex due to simultaneously occurring of mass transfer, substrate conversion and cell growth. Entrapped cells cannot be uniformly bathed in a bulk nutrient medium, but rather diffusedly fed from the contact surface separating the medium from the immobilized cells [7]. During the biocatalytic conversion, the net fluxes of substrates and products in and out of the gel, in case of a diffusion-controlled transport, are driven by concentration gradients of the reactants. The local steepness of the gradients depends on the conversion and transport rates, as well as the gel size and porosity, cell loading and intraparticle reactant diffusivity [8]. Transport properties, particularly diffusion coefficients, provide a direct measure of molecular mobility, an important factor for the preservation of biological materials in gel matrices [9]. Diffusion coefficients under various conditions are needed to model the diffusion kinetics of the system. The feed substrate concentration and residence time may be manipulated to control cell growth. Some growth can be desirable, but sometimes overgrowth can cause cell leakage, breaking of the carrier and consequently lowering the product yields. Additionally, the presence of the cells in the gel can also cause alteration of the diffusion coefficients [10].

Two of the most common methods for determining diffusion coefficient are the nonsteady state method and the diaphragm diffusion chamber method. With the non-steady state method the diffusion rate is measured while the solute diffuses into or out of gel beads in a wellstirred solution [11]. The diffusion chamber method is reliable for measuring diffusion trough gel plates with uniform thickness [12]. The basic idea of the chamber is very simple: the diffusion flux through a gel membrane, separating two compartments, is studied. This type of chamber has been improved over the years $[10,13]$.

In this study different diffusion models were tested to select the most suitable model for measuring the diffusion trough hydroxyethylcellulose (HEC) gels. Diffusion coefficients for glucose and ethanol for pure gels and gels loaded with cells were determined. The diffusion properties of the HEC gels were tested in a real system, which is fermentation of glucose to ethanol by immobilized Saccharomyces cerevisiae cells.

\section{MATERIALS AND METHODS}

\subsection{Materials}

Natrosol (2-hydroxyethylcellulose) $\left(\mathrm{Mn}=1.3 \times 10^{6} \mathrm{~g} / \mathrm{mol}\right)$ was obtained from Union Carbide Chemicals and Plastics Co. The (4-benzoylbenzyl)trimethylammonium chloride (BBTMAC) was purchased from Aldrich and was used as a photoinitiator without further purification. All other chemicals used were purchased from commercial sources and were of analytical grade. 


\subsection{Yeast, medium and inoculum preparation}

The yeast used in this study was a commercial grade baker's yeast, Saccharomyces cerevisiae. The cells were grown in a medium with the following composition (per liter distilled water): $10 \mathrm{~g}$ yeast extract, $2 \mathrm{~g} \mathrm{KH}_{2} \mathrm{PO}_{4}$, $1 \mathrm{~g} \mathrm{NaCl}, 0.2 \mathrm{~g} \mathrm{CaCl}_{2} \cdot 2 \mathrm{H}_{2} \mathrm{O}, 1.7 \mathrm{~g} \mathrm{MgSO}_{4} \cdot 7 \mathrm{H}_{2} \mathrm{O}$, $0.01 \mathrm{~g} \mathrm{FeCl}_{3} \cdot 6 \mathrm{H}_{2} \mathrm{O}, 2 \mathrm{~g} \mathrm{NH}_{4} \mathrm{Cl}$ and $100 \mathrm{~g}$ glucose. The sugar and salt solutions were autoclaved separately at $121^{\circ} \mathrm{C}$ for $15 \mathrm{~min}$. The initial $\mathrm{pH}$ was 5 .

\subsection{Preparation of cryogels, without and with yeast cells}

Hydroxyethylcellulose was dissolved in an appropriate amount of distilled water to obtain $2 \%$ aqueous solution at $40{ }^{\circ} \mathrm{C}$. Then the solution was kept for $24 \mathrm{~h}$ at room temperature to ensure complete dissolution and homogeneity. Given amount of photoinitiator, (4-benzoylbenzyl)trimethylammonium chloride, BBTMAC, (2 wt \% of the polymer mass) dissolved in $1 \mathrm{~mL}$ distilled water was added under stirring at room temperature. The homogeneous solution was poured into Teflon dishes with $20 \mathrm{~mm}$ diameter, forming a $2-3 \mathrm{~mm}$ thick layer, followed by freezing step at $-30{ }^{\circ} \mathrm{C}$ for $2 \mathrm{~h}$. Afterwards the dishes were quickly placed in a temperature-controlled chamber and the polymer was UV irradiated in a Dimax 5000-EC UV light curing system for 2 minutes. The gels in the Teflon dishes were left at room temperature for few minutes, turned over the other side and placed back in the freezer for additional $2 \mathrm{~h}$, when they were UV irradiated again on the other side for 2 minutes under same conditions.

Cells of Saccharomyces cerevisiae were immobilized in hydroxyethylcellulose cryogels. Homogenized cell suspension, containing $15 \%(\mathrm{w} / \mathrm{v})$ with respect to the polymer solution, was added under stirring at room temperature to the $2 \%(\mathrm{w} / \mathrm{w})$ aqueous solution of HEC and vortexed. The resulting homogeneous solution was poured into the same Teflon dishes (previously mentioned) forming about $2.5 \mathrm{~mm}$ thick layer and frozen at $-30{ }^{\circ} \mathrm{C}$ for $2 \mathrm{~h}$. The dishes were then irradiated with UV light by Dymax 5000-EC curing equipment with $400 \mathrm{~W}$ metal halide flood lamp following the same procedure. After immobilization procedure the gels were lyophilized.

\subsection{Gel membrane characterization}

The gel membrane characterization was performed via measuring the equilibrium degree of swelling (ES) at room temperature. Disks of dried gel were equilibrated in distilled water for $48 \mathrm{~h}$, removed from the water, blotted with filter paper and weighed. They were then dried to constant mass under vacuum and weighed again. The ES is presented as grams of swollen gel sample per gram of dried gel sample:

Equilibrium swelling $=$

$$
=\frac{\text { mass of equilibrated swollen sample }}{\text { mass of dry sample }}
$$

\subsection{Diffusion measurements}

These measurements were performed in a Plexiglas chamber consisting of two separate cells with double jacketed walls as described earlier [14]. Each cell represented a cylinder of $200 \mathrm{~mL}$ volume (Figure 1). The temperature was kept at $28 \pm 1{ }^{\circ} \mathrm{C}$. The cells were held together with clamps and the area around the junction was sealed with parafilm. One of the cells was filled with distilled water and used as an acceptor cell and the other one was a donor cell filled with the solution examined. Both cells were stirred mechanically. Samples were withdrawn periodically. The membranes, tested for diffusion of glucose and ethanol, were made in special dishes with a diameter of $36 \mathrm{~mm}$ by the same procedure, previously described, for synthesis of the cryogels. Before the start of the diffusion measurements the membranes were mounted in the chamber and pre-swollen in 


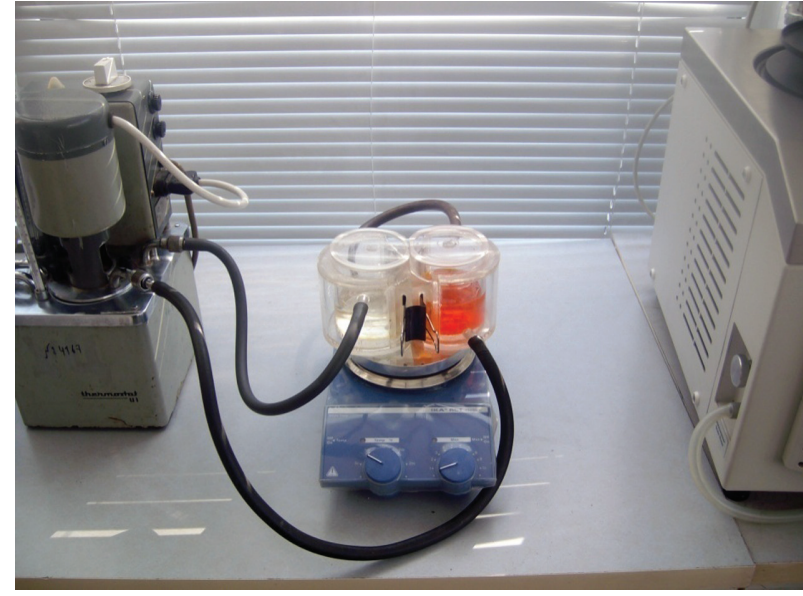

Fig. 1. Two compartment plexiglass chamber for diffusion measurements.

distilled water for $24 \mathrm{~h}$ at room temperature.

\subsection{Fermentations}

Batch fermentations with immobilized cells of Saccharomyces cerevisiae were carried out in $100 \mathrm{~mL}$ nutrient medium placed in a 250 $\mathrm{mL}$ Erlenmeyer flask on a rotary shaker (100 rpm) at $28^{\circ} \mathrm{C}$. After 20 hours of preculturing, the gels with immobilized cells were washed in sterile distilled water and transferred into fresh nutrient medium for ethanol fermentation, under same conditions. Forty gel pieces were placed in each flask providing $40 \mathrm{~mL}$ to $100 \mathrm{~mL}$ volume ratio of gel to medium.

For repeated batch fermentation after every cycle the immobilized biocatalysts were recovered from the flasks and were immersed in fresh medium to start a new batch cycle.

\subsection{Analytical methods}

In batch fermentation, approximately $2 \mathrm{~mL}$ samples were collected for analysis. Dry weight of yeast cells in the gels was estimated by the Kjeldahl method. Gels used for this procedure were removed from the fermentation medium, blotted with filter paper and weighed before pyrolysis. To determine the degree of cell leakage from the matrices, after the immobilization procedure, the cell concentration in the fermentation broth was calculated by measuring the absorbance of each sample withdrawn from the medium at $620 \mathrm{~nm}$ using spectrophotometer, Varian, Cary 50.

Ethanol was analyzed by gas chromatography using a Varian CP 3800 with a capillary column WCOT fused silica $(30 \mathrm{~m}$ $\times 0.32 \mathrm{~mm}$ ), CP WAX $52 \mathrm{CB}, \mathrm{d}_{\mathrm{i}}=0.25 \mu \mathrm{m}$, equipped with flame ionization detector (FID) and a manual injector type 1709 . The injector and detector temperatures were $250{ }^{\circ} \mathrm{C}$, and the column temperature was $200{ }^{\circ} \mathrm{C}$. Nitrogen was used as a carrier gas with a flow rate of 30 $\mathrm{mL} / \mathrm{min}$. Isopropanol was used as an internal standard.

Glucose concentration was determined using a reducing chemical reagent, 3,5-dinitrosalycilic acid solution following the procedure described by Miller.

\subsection{Calculation of fermentative parameters}

Ethanol yield was calculated as mass of the ethanol formed per mass of the glucose consumed, while the volumetric productivity was calculated as mass of the ethanol formed per liter medium per hour.

The suitability of carriers for cell immobilization is estimated by determination of the cell retention and immobilization efficiency. Cell retention, $R_{\mathrm{c}}$, was calculated by dividing the mass of the entrapped cells with the mass of the matrix used for cell immobilization. The immobilization efficiency, $\eta$, represents the ratio of the concentration of the immobilized cells to the concentration of the total cells, immobilized plus free cells.

\section{RESULTS AND DISCUSSION}

\subsection{Selection of a diffusion model}

Different approaches to describe diffusion data can be found in the literature. Awide-ranging summary of these theories based on a solution of Fick's first law for different geometries is given in Table 1. Most of the models are 
referring to diffusion in gel beads while a few to diffusion in gel membranes. The diffusion theory originally developed for polymers with a moderate solvent content has been successfully extrapolated to gels, especially to cryogels. Our hydroxyethylcellulose cryogels were synthesized as gel membranes, and therefore, the models 6 (pseudo-steady state model) [20], 7 (steady-state model) [21] and 10 (lag-time model) [10], describing the diffusion in gel membranes were selected for further studies. These HEC cryogels distinguished themselves with heterogeneity, chemical inertness and uniform distribution of pores [27].

Each of the selected models has its own specificities. According to the pseudo steady state model, all data before reaching the steady state condition are neglected. The characteris-

Table 1

\section{Diffusion models}

\begin{tabular}{|c|c|c|c|}
\hline No & Model & Equation & Ref. \\
\hline 1 & Mackie and Mears theory & $\frac{D_{\bar{D}}}{D_{0}}=\frac{\left(1-\Phi_{p}\right)^{2}}{\left(1+\Phi_{p}\right)^{2}}$ & {$[15]$} \\
\hline 2 & Ogston theory & $\frac{D}{D_{0}}=e^{\left[-\oplus \dot{p} \cdot \frac{R_{A}+R_{B}}{R_{F}}\right]}$ & {$[16]$} \\
\hline 3 & Free volume theory & $\frac{D}{D_{0}}=e^{\left[-\frac{\dot{\dot{q}_{p}}}{1-\dot{\varphi}_{p}}\right]}$ & {$[17]$} \\
\hline 4 & Renkin model & $\frac{D}{D_{0}}=\left(\frac{1-\Phi_{p}}{\tau^{2}}\right) Z$ & {$[18]$} \\
\hline 5 & Namikawa theory & $\frac{D}{D_{0}}=\frac{1}{2}\left(1+\frac{K_{H}-n C_{p}+n C_{A}}{\left(B^{2}+4 n C_{A} K_{H}\right)^{0.5}}\right)$ & [19] \\
\hline 6 & Pseudo-steady-state model & $\ln \left(\frac{C_{L A}-C_{L B}}{C_{L A 1}-C_{L B 1}}\right)=-\frac{D_{\theta} A}{l}\left(\frac{1}{V_{A}}-\frac{1}{V_{B}}\right)\left(t-t_{1}\right)$ & {$[20]$} \\
\hline 7 & Steady-state model & $Q=\frac{D_{\theta} A C_{L A o}}{l} t$ & {$[21]$} \\
\hline 8 & Laplace approach & $\frac{D_{e}}{D_{0}}=\frac{\left(1-\Phi_{p}\right)}{1+\frac{\Phi_{p}}{q}}$ & {$[22]$} \\
\hline 9 & Hydrodynamic model & $\frac{D}{D_{0}}=e^{-k R_{A}}$ & {$[23]$} \\
\hline 10 & Lag-time model & $Q=\frac{A k C_{L A} D}{l}\left(t-\frac{l^{2}}{6 D}\right)$ & {$[10]$} \\
\hline 11 & Simple pore model & $\frac{D_{e}}{D_{0}}=\left(1-\Phi_{p}\right)^{2}$ & {$[24]$} \\
\hline 12 & Lustig and Pepas theory & $\frac{D}{D_{0}}=K\left(1-\frac{R_{A}}{R_{p}}\right) e^{\left(\frac{-\dot{\dot{q}} p}{1-\dot{\phi} p}\right)}$ & {$[25]$} \\
\hline 13 & $\begin{array}{l}\text { Hydrodynamic scaling } \\
\text { model }\end{array}$ & $\frac{D}{D_{0}}=e^{-\alpha \dot{\varphi} \varphi}$ & {$[26]$} \\
\hline
\end{tabular}


tics of the steady-state model are that the concentration of the solute in the membrane is required for calculating the accurate diffusion coefficient. The lag-time method takes into consideration all measured data including the lag time before reaching the steady-state condition. The linearization of these three models is presented in Figure 2. Fitting of our experimental data (glucose and ethanol concentrations) into the selected models gave correlation factors above 0.95 in all cases, with the highest correlation factor of 0.99 for the lag-time method (Table 2). Consequently, this method was used for measuring the diffusion coefficient of glucose and ethanol trough the hydroxyethylcellulose gels.

T a b 1 e 2

Selected models for measuring the diffusion coefficients in gels

\begin{tabular}{llc}
\hline \hline \multicolumn{1}{c}{ Model } & \multicolumn{2}{c}{ Correlation factor, $\mathrm{R}^{2}$} \\
& Glucose & Ethanol \\
\hline $\begin{array}{l}\text { pseudo-steady- } \\
\text { state }\end{array}$ & 0.980 & 0.992 \\
steady-state & 0.990 & 0.995 \\
lag-time & 0.992 & 0.997 \\
\hline \hline
\end{tabular}

By rearranging the equation (2):

$$
Q=\frac{A D C_{0}}{l}\left(t_{s}-\frac{l^{2}}{6 D}\right)
$$

a mathematical solution for calculating the diffusion coefficient was derived:

$$
D=\frac{l^{2}}{6 t_{L}}
$$

As can be seen from the equation (3) the diffusion coefficient can be easily calculated if membrane thickness, $l$, and the lag time,
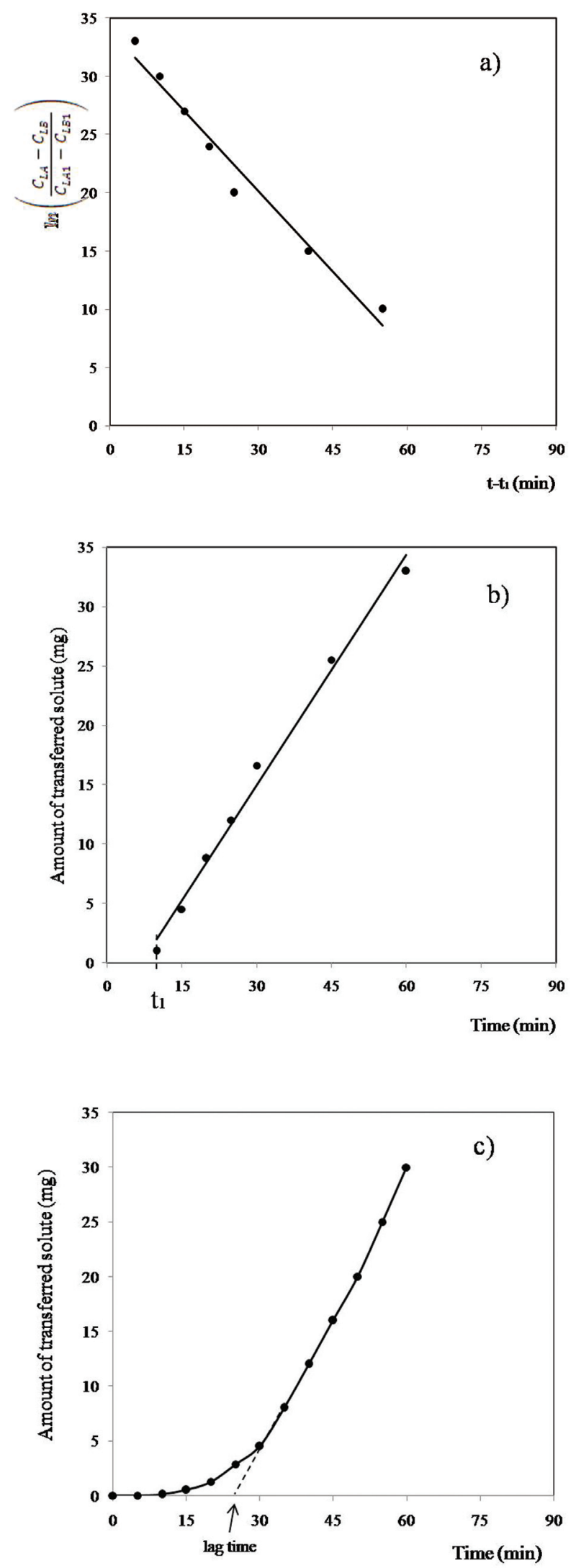

Fig. 2. Graphic presentation of pseudo-steady state (a), steady state (b) and lag time method (c) for diffusion of solutes 
$t_{\mathrm{L}}$ of transferred solutes are known. The lag time can be estimated from the intercept of the time axes and extrapolated straight line of the data representing the transferred solute (Figures 3 and 4). Figures 3 and 4 represent the experimental graphs of the total amount of glucose and ethanol transferred trough pure hydroxyethylcellulose cryogels and gels loaded with yeast cells.

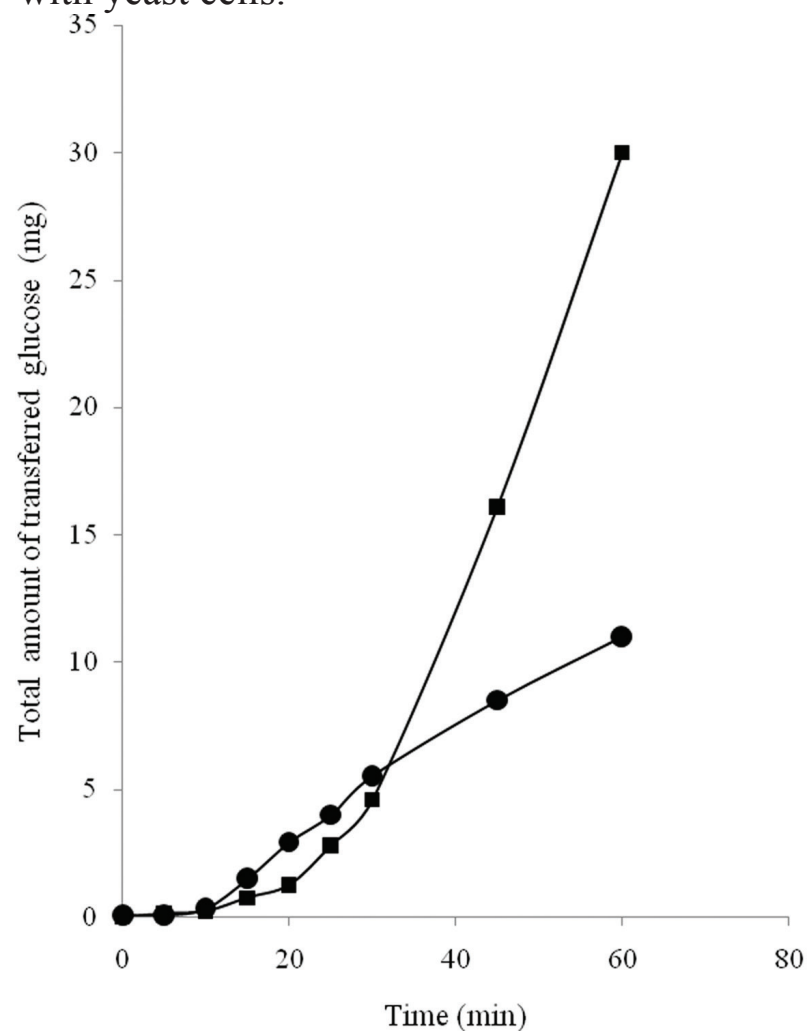

Fig. 3. Lag time for solute diffusion in $2 \%$ hydroxyethylcellulose cryogel: $(-\bullet-)$ glucose diffusion through pure gels, (-m-) Glucose diffusion through gels with entrapped cells. (glucose concentration, $\left.\mathrm{C}_{0}=100 \mathrm{~g} / \mathrm{L}, \mathrm{A}=5.3 \mathrm{~cm}^{2}, 1=0.15 \mathrm{~cm}, \mathrm{t}_{\mathrm{s}}=60 \mathrm{~min}\right)$.

Many authors have reported the measurements of effective diffusivities for substrates and metabolic products within gel matrices in the form of beads or large membranes without cells (Table 3). The diffusion coefficients for glucose and ethanol through the HEC cryogel given in Table 3 are similar to the diffusion rates of these solutes in liquids, and comparable to the diffusion coefficients of the same solutes trough other types of gel matrices. Nakanishi et al. [29] had reported a value of $3.1 \times 10^{-6} \mathrm{~cm}^{2} / \mathrm{s}$ for glucose diffusion

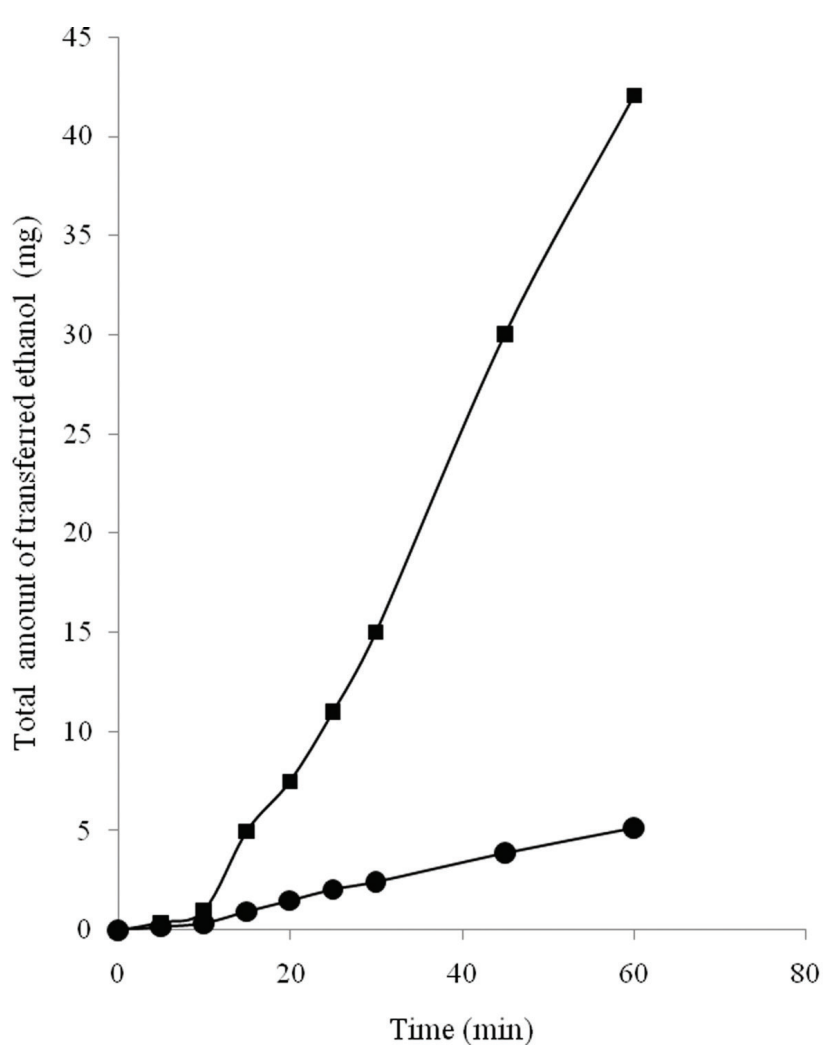

Fig. 4. Lag-time for solute diffusion in $2 \%$ hydroxyethylcellulose cryogel: (-๑-) ethanol diffusion through pure gels, (-ø-) ethanol diffusion through gels with entrapped cells. (ethanol concentration, $C_{0}=81 \mathrm{~g} / \mathrm{L}$, $\left.A=5.3 \mathrm{~cm}^{2}, l=0.15 \mathrm{~cm}, t_{\mathrm{s}}=60 \mathrm{~min}\right)$.

$\mathrm{T}$ a b 1 e 3

Diffusion coefficients for glucose and ethanol through cell free gel membranes

\begin{tabular}{|c|c|c|c|}
\hline \multirow[t]{2}{*}{ Medium } & \multicolumn{2}{|c|}{$\begin{array}{l}\text { Diffusion coefficients } \\
\qquad\left(\mathrm{cm}^{2} / \mathrm{s}\right)\end{array}$} & \multirow[t]{2}{*}{ Ref. } \\
\hline & Glucose & Ethanol & \\
\hline Water & $6.67 .10^{-6}$ & $1.1 .10^{-5}$ & {$[28]$} \\
\hline Dextran & $5.80 .10^{-6}$ & / & [19] \\
\hline $\begin{array}{l}\text { Photo-crosslinkable } \\
\text { resin }\end{array}$ & $3.10 .10^{-6}$ & / & [29] \\
\hline Ca-alginate beads & $6.70 .10^{-6}$ & / & {$[30]$} \\
\hline Ca-alginate membrane & $6.10 .10^{-6}$ & $1.00 .10^{-5}$ & {$[10]$} \\
\hline $\begin{array}{l}\text { Ca-alginate beads } \\
\text {-monolayer }\end{array}$ & $6.20 .10^{-6}$ & $0.99 .10^{-5}$ & {$[31]$} \\
\hline $\begin{array}{l}\text { Ca-alginate beads } \\
\text {-double layer }\end{array}$ & $6.23 \cdot 10^{-6}$ & $0.99 .10^{-5}$ & {$[31]$} \\
\hline Agarose & / & $0.92 .10^{-5}$ & {$[32]$} \\
\hline Carraginane & $3.70 .10^{-6}$ & / & [33] \\
\hline Gelatine & $3.20 .10^{-6}$ & / & {$[7]$} \\
\hline Polyacrilamide & $2.90 .10^{-6}$ & / & [34] \\
\hline Poly(ethylene oxide) & $2.00 .10^{-6}$ & / & {$[35]$} \\
\hline Hydroxyethylcellulose & $3.90 .10^{-6}$ & $0.97 .10^{-5}$ & {$[14]$} \\
\hline
\end{tabular}


trough photo-crosslinkable resin, which is very similar to the value we obtained. In this study, our focus was on the diffusivity of the glucose and ethanol that is substrate and product, through hydroxyethylcellulose cryogel loaded with cells. The diffusion coefficient of glucose and ethanol through the gel with immobilized cells had values of $6.9 \times 10^{-6} \mathrm{~cm}^{2} / \mathrm{s}$ and $2.5 \times 10^{-5}$ $\mathrm{cm}^{2} / \mathrm{s}$, respectively. The slower diffusion rates of glucose and ethanol in cell-loaded gels is probably due to the decrease in the number and length of the free pores rather than a decrease in their diameters [27]. In these gels the diffusion was controlled by the rate at which the solutes

$\mathrm{Tab} l \mathrm{e} 4$

Characterization of hydroxyethylcellulose membranes without and with entrapped cells

\begin{tabular}{ccc}
\hline \hline $\begin{array}{c}\text { Gel composition } \\
\text { HEC: cells } \\
\%(w / w)\end{array}$ & $\begin{array}{c}\text { Gel composition } \\
\text { HEC: cells } \\
\%(\mathrm{w} / \mathrm{v})\end{array}$ & ES \\
\hline $1: 0$ & 0 & 24 \\
$1: 6$ & 15 & 18 \\
\hline \hline
\end{tabular}

diffuse trough the cells occupying the pores. Still, the diffusion coefficients obtained were within comparable range of the diffusion coefficients through pure gels, proving that the cells inside the matrix did not cause a barrier for the transport of the solute molecules. It is evident that solutes such as glucose and ethanol with diameters of 7.2 and $4.5 \AA$, can smoothly pass through both pure and cell loaded cryogel.
From the numerous studies on the variables affecting the solute transport, it has been established that the transport depends on mesh size, swelling ratio, ionization, ionic strength, $\mathrm{pH}$ values and temperature [36]. Another feature of the gels important for the solute transport is the ability of the gels to absorb and hold in their structure, a certain amount of the solvent. For measurements of the amount of transferred solute we used preswollen membrane in the diffusion chamber. The equilibrium degree of swelling for the pure gels, as well as gels with entrapped cells, is presented in Table 4 . The presence of entrapped cells did not hinder the swelling of the gels, proving that besides the cells there was enough space in the porous structure of the gel for absorbing solutes from the nutrient medium.

\subsection{Testing of the diffusion properties of the gel in the fermentative process}

The calculated values for cell retention $\left(R_{\mathrm{c}}\right)$ and immobilization efficiency $(\eta)$ are presented in Table 5. These two parameters apart from characterizing the efficiency of cell immobilization, are also very good and useful indicators of the diffusivity of the solutes trough the gels. The immobilization efficiency was around $0.92 \pm 0.03$ throughout the batches, while the cell retention values were around $0.20 \pm 0.03 \mathrm{~g}_{\text {cell }} / \mathrm{g}_{\mathrm{gel}}$. The values of the immobilization efficiency and the cell retention confirmed the ability of HEC cryogels to

Table 5

Kinetic and immobilization parameters of ethanol production from glucose medium by Saccharomyces cerevisiae cells immobilized in cryogels and used in repeated batch fermentation. The initial dry biomass entrapped in the gels was $17.64 \mathrm{~g} / \mathrm{L}, t=60 \mathrm{~h}$.

\begin{tabular}{ccccccccc}
\hline \hline & \multicolumn{10}{c}{ Parameter } \\
\hline \multirow{2}{*}{ Batch } & $\begin{array}{c}\mathrm{P} \\
(\mathrm{g} / \mathrm{L})\end{array}$ & $\begin{array}{c}\mathrm{Y}_{\mathrm{p} / \mathrm{s}} \\
(\mathrm{g} / \mathrm{g})\end{array}$ & $\begin{array}{c}\mathrm{Y}_{\mathrm{p} / \mathrm{t}} \\
(\%)\end{array}$ & $\begin{array}{c}\mathrm{Q}_{\mathrm{p}} \\
(\mathrm{g} / \mathrm{L} \cdot \mathrm{h})\end{array}$ & $\begin{array}{c}\mathrm{S}_{\text {residual }} \\
(\mathrm{g} / \mathrm{L})\end{array}$ & $\begin{array}{c}\Delta \mathrm{S} / \mathrm{S}_{0} \\
(\%)\end{array}$ & $\begin{array}{c}\mathrm{R}_{\mathrm{c}} \\
(\text { gcell/ggel })\end{array}$ & $\eta$ \\
\hline I & 33.4 & 0.35 & 69 & 0.56 & 5.60 & 94 & 0.20 & 0.92 \\
\hline II & 33.0 & 0.35 & 69 & 0.55 & 6.84 & 93 & 0.22 & 0.95 \\
III & 29.6 & 0.31 & 60 & 0.49 & 7.10 & 93 & 0.18 & 0.89 \\
\hline \hline
\end{tabular}


serve as immobilization matrices for the cells of Saccharomyces cerevisiae. These two parameters, along with the equilibrium swelling and the diffusion coefficients, demonstrated that the cryogels are porous enough to hold the cells inside the matrix and enable easy diffusion of the substrate and product molecules trough the gel.

To confirm the good diffusivity properties of the HEC gel in real system, repeated batch fermentation with immobilized cells was performed. Immobilized Saccharomyces cerevisiae cells were used in three repetitive runs for conversion of glucose to ethanol (Table 5). The production of ethanol at the end of the three runs ranged from 30 to $34 \mathrm{~g} / \mathrm{L}$. The residual sugar concentrations were low in all cases $(5.0-7.0 \mathrm{~g} / \mathrm{L})$ with conversions from 93 $\%$ to $94 \%$, demonstrating good diffusivity of the system. The final product yields achieved by the cells immobilized in cryogels were in the range from 60 to $69 \%$ of the theoretical yield, proving the acceptable performance of the immobilized system. The product yield above $60 \%$ with the immobilized cells is 1.3 times higher than the product yield of the fermentation process carried out with free yeast cells [27]. The maximal volumetric productivities of 1.36, 1.98 and $1.49 \mathrm{~g} / \mathrm{L} \cdot \mathrm{h}$ in the first, second and the third batch reached after $12 \mathrm{~h}$ of cultivation, also go in line with the maximal volumetric productivity of $1.35 \mathrm{~g} / \mathrm{L} \cdot \mathrm{h}$ for the process with free cells.

\section{CONCLUSION}

The lag-time model was selected as accurate, rapid and reliable model for measuring diffusivity of solutes. The diffusion coefficients of glucose and ethanol through the hydroxyethylcellulose cryogels with immobilized cells had values of $6.9 \times 10^{-6} \mathrm{~cm}^{2} / \mathrm{s}$ and $2.5 \times 10^{-5} \mathrm{~cm}^{2} / \mathrm{s}$, respectively. The cells inside the matrix did not profoundly change the swelling properties of the gel and did not cause a diffusional barrier for the transport of the solute molecules. Testing the diffusivity of the substrate and product through the gel in a real system proved that this immobilized system is satisfactory and can be compared with the free cell system.

Acknowledgements. The authors acknowledge the financial support of the Macedonian Ministry of Education and Science, and express their gratitude to Prof. Christo Tsvetanov and his coworkers of the Institute of Polymers at the Bulgarian Academy of Sciences where the preparation and characterization of the cryogels were performed.

\section{NOMENCLATURE}

$\begin{array}{ll}\text { A } & \text { membrane area, } \mathrm{cm}^{2} \\ \text { BBTMAC } & \text { (4-benzoylbenzyl)trimethylammonium chloride } \\ \mathrm{C}_{0} & \text { initial concentration of solute, } \mathrm{g} / \mathrm{L} \\ \mathrm{C}_{\mathrm{L}}, \mathrm{C}_{\mathrm{LA}}, \mathrm{C}_{\mathrm{LB}} & \begin{array}{l}\text { concentration of liquids in pore, } \mathrm{g} / \mathrm{L} \\ \text { diffusion coefficient, } \mathrm{cm}^{2} / \mathrm{s}\end{array} \\ \mathrm{D} & \text { effective diffusion coefficient, } \mathrm{cm}^{2} / \mathrm{s} \\ \mathrm{D}_{\mathrm{e}} & \text { diffusion coefficient in water, } \mathrm{cm}^{2} / \mathrm{s} \\ \mathrm{D}_{0} & \text { equilibrium swelling degree } \\ \mathrm{ES} & \text { hydroxyethylcellulose } \\ \mathrm{HEC} & \text { constant } \\ \mathrm{K} & \text { partition coefficient } \\ \mathrm{k} & \text { membrane thickness, mm } \\ \mathrm{l} & \text { constant } \\ \mathrm{n} & \text { product (ethanol) concentration, } \mathrm{g} / \mathrm{L} \\ \mathrm{P} & \end{array}$




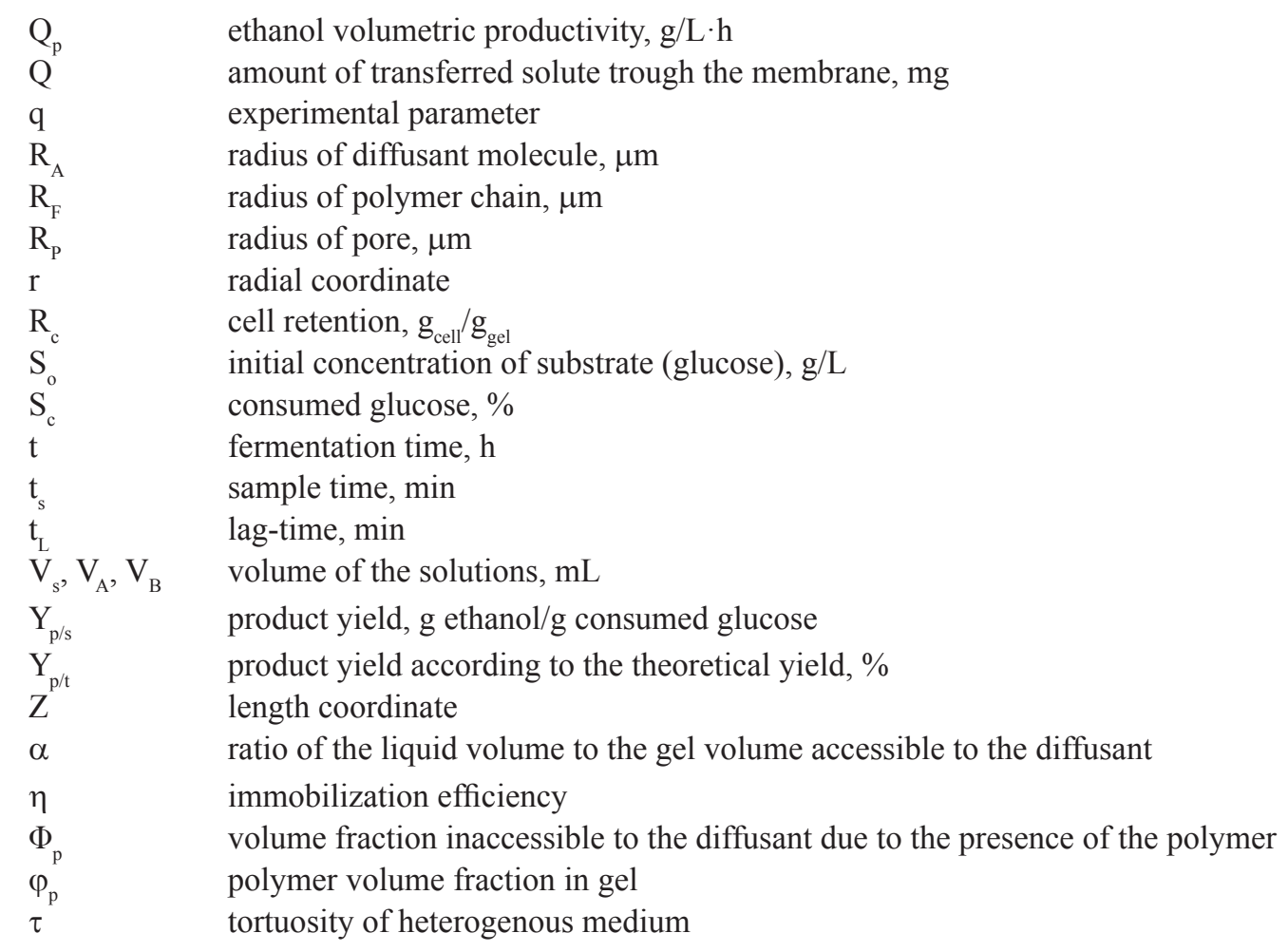

\section{REFERENCES}

[1] K.D. Vorlop, J. Beyersdorf, A. Muscat, Entrapment of microbial cells within polyurethane hydrogel beads with the advantage of low toxicity. Biotechnol. Techn. 6 (1992), 483-488.

[2] G.F. Bickerstaff, Immobilization of Enzymes and Cells: Some Practical Considerations. In: Bickerstaff, G. F., editor: Methods in Biotechnology Vol 1. Totowa, NJ: Humana Press Inc., (1997), 1-11.

[3] P. Karagöz, E. Erhan, B. Keskinler, M. Özkan, The use of microporous divinyl benzene copolymer for yeast cell immobilization and ethanol production in packed-bed reactor. Appl. Biochem. Biotechnol., 152, (2009) 66-73.

[4] P.Petrov., E. Petrova, B. Tchorbanov, Ch. Tsvetanov, Synthesis of biodegradable hydroxyethylcellulose cryogels by UV irradiation. Polymer, 48, (2007), 4943-4949.

[5] E. Winkelhausen, R. Jovanovic-Malinovska, S. Kuzmanova, M. Cvetkovska, Ch. Tsvetanov, Hydrogels based on u.v.-crosslinked poly(ethylene oxide) - matrices for immobilization of Candida boidinii cells for xylitol production. World J. Microbiol. Biotechnol., 24 (2008), 2035-2043.

[6] V. I. Lozinsky, Polymeric cryogels as a new family of macroporous and supermacroporous materials for biotechnological purposes. Russ. Chem. Bull. International Edition, 57 (2008), 1015-1032.

[7] E. deAlteriis, D. Porro, V. Romano, P. Parascandola, Relation between growth dynamics and diffusional limitations in Saccharomyces cerevisiae cells growing as entrapped in an insolubilised gelatine gel. FEMS Microbiol. Lett., 195 (2001), 245-251.

[8] J. L. van Roon, M.M.H.D. Arntz, A. I. Kallenberg, M. A. Paasman, J. Tramper, C. G. P. H. Schroen, H. H. Beeftink, A multicomponent reaction-diffusion model of a heterogeneously distributed immobilized enzyme. Appl. Microbiol. Biotechnol., 72 (2006), 263-278.

[9] A. C. F. Ribeiro, O. Ortona, S. M. N. Simoes, C. I. A. V. Santos, P. M. R. A. Prazeres, A. J. M. Valente, V. M. M. Lobo, H. D. Burrows, Binary mutual diffusion coefficients of aqueous solutions of sucrose, 
lactose, glucose and fructose in the temperature range from (298.15 to 328.15) K. J. Chem. Eng. Data, 51 (2006), 1836-1840.

[10] B. J. M. Hannoun, G. Stephanopoulos, Diffusion coefficients of glucose and ethanol in cell-free and cell-occupied calcium alginate membranes. Biotechnol. Bioeng., 28 (1986), 829-835.

[11] Axelsson, B. Persson, Determination of effective diffusion coefficients in calcium alginate gel plates with varying yeast cell content. Appl. Biochem. Biotechnol, 18 (1988), 231-250.

[12] W. Zhang, C. M. M. Franco, Critical assessment of quasi-steady-state method to determine effective diffusivities in alginate gel membranes. Biochem. Eng. J., 4 (1999), 55-63.

[13] T. Riede, E. U. Schlunder, Diffusivities of the ternary liquid mixture 2-propanol-water-glycerol and three-component mass transfer in liquid. Chem. Eng. Sci., 46 (1991), 609-617.

[14] E. Velickova, P. Petrov, Ch. Tsvetanov, S. Kuzmanova, M. Cvetkovska, E. Winkelhausen, Entrapment of Saccharomyces cerevisiae cells in u.v. crosslinked hydroxyethylcellulose/ poly(ethylene oxide) double-layered gels. React. Funct. Polym., 70 (2010), 908-915.

[15] J. S. Mackie, P. Meares, The diffusion of electrolytes in a cation-exchange resin membrane I. Theoretical. Proc. R. Soc. Lond., A232 (1955), 498-509.

[16] A. G. Ogston, The space in a uniform random suspension of fibres. Trans. Far. Soc., 54 (1958), 1754-1757.

[17] S. U. Li, J. L. Gainer, Diffusion in polymer solutions. Ind. Eng. Chem. Fund, 7 (1968), 432 440.

[18] R.E. Beck, J.S. Schultz, Hindrance of solute diffusion within membranes as measured with microporous membranes of known pore geometry. Biochem Biphys Acta, 255 (1972), 273-303.

[19] R. Namikawa, H. Okazaki, K. Nakanishi, R. Matsuno, T. Kamikubo, Diffusion of saccharides and amino acids in solutions of dextrans and its derivatives. Agric. Biol. Chem., 41 (1977), 1003 1009.

[20] H. Braselman, J. Vacik, J. Kopecek, D. Kirstein, Regulation of transport in artificial membranes by environmental hydrogen-ion concentration. Eur. Polym. J., 16 (1980), 431-435.
[21] J. Klein, P. Schara, Entrapment of living microbial cells in covalent polymeric networks, II. A quantitative study on the kinetics of oxidative phenol degradation by entrapped Candida tropicalis cells. App. Biochem. Biotechnol., 6 (1981), 91-117.

[22] A. H. Muhr, J. M. V. Blanshard, Diffusion in gels. Polym., 23 (1982), 1012-1026.

[23] R. I. Cukier, Diffusion of Brownian spheres in semidilute polymer solutions. Macromolecules, 17 (1984), 252-255.

[24] K. A. Akanni, J. W. Evans, I. S. Abramson, Effective transport coefficients in heterogeneous media. Chem. Eng. Sci., 42 (1987), 1945-1954.

[25] S. R. Lustig, N. A. Peppas, Solute diffusion in swollen membranes, IX. Scaling laws for solute diffusion in gels. J. Appl. Polym. Sci., 36 (1988), $735-747$.

[26] G. D. J. Philies, The hydrodynamic scaling model for polymer self diffusion. J. Phys. Chem., 93 (1989), 5029-5039.

[27] E. Velickova, E. Winkelhausen, S. Kuzmanova, M. Cvetkovska, Ch. Tsvetanov, Hydroxyethylcellulose cryogels used for entrapment of Saccharomyces cerevisiae cells. React. Funct. Polym., 69 (2009), 688-693.

[28] L. G. Longsworth, The diffusion of electrolytes and macromolecules in solution: a historic survey. Ann. NY Acad. Sci., 46 (1945), 211-240.

[29] K. Nakanishi, S. Adachi, S. Yamamoto, R. Matsuno, A. Tanaka, T. Kamikubo, Diffusion of saccharides and amino acids in cross-linked polymers. Agric. Biol. Chem., 41 (1977), 2455-2462.

[30] H. Tanaka, M. Matsumura, I. A. Veliky, Diffusion characteristics of substrates in Ca-alginate gel beads. Biotechnol. Bioeng., 26 (1984), 53-58.

[31] S. Kuzmanova, S. Žerajic, E. Vandeska, F. Poposka, Physical studies of yeast cell immobilization in two-layer alginate gel beads. II. Diffusion characteristics. Kem. Ind., 39 (1990), 421-428.

[32] B.A. Westrin, Diffusion measurements in gels. A methodological study. $\mathrm{PhD}$ thesis, Department of Chemical Engineering I. Lund University, Sweden (1991).

[33] M. A. Taipa, J. M. S. Cabral, H. Santos, Comparison of glucose fermentation by suspended and gelentrapped yeast cells: an in vivo nuclear magnetic resonance study. Biotechnol. Bioeng., 41 (1993), 647-653. 
[34] D. Yankov, Diffusion of glucose and maltose in polyacrylamide gel. Enzyme Microb. Technol., 34 (2004), 603-610.

[35] S. S. Jang, W. A. Goddard III, M. Yashar, S. Kalani, Mechanical and transport properties of the poly(ethylene oxide)-poly(acrylic acid) double network hydrogel from molecular dynamic simulations. J. Phys. Chem. B, 111 (2007), 17291737.

[36] J. L. Stringer, N. A. Peppas, Diffusion of small molecular weight drugs in radiation-crosslinked poly(ethylene oxide) hydrogels. J. Control. Release, 42 (1996), 195-202. 